\title{
The Biographical and Human Resource Management Predictors of Union Membership Engagement of Low- and Middle-Income Workers
}

\author{
Molefe Jonathan Maleka \\ Tshwane University of Technology, Pretoria, South Africa \\ Malekam@tut.ac.za
}

\begin{abstract}
In this study, the researcher investigated the biographical and human resource management (HRM) predictors of union membership. The literature reviewed revealed that there is little research on this topic in the South African context. The literature reviewed also showed that males, permanent employees, employees who are less committed, who have a level of quality of work-life (QWL) and engagement, and those who are satisfied are more likely to be unionized. A cross-sectional survey design was used to address the research questions. One thousand questionnaires were distributed and 874 were completed by the respondents at Marabastad Mall in the City of Tshwane Metropolitan Municipality (CTMM) in South Africa. The study results showed that employment status was the highest predictor $(\beta=-1.782, p<0.05)$ of union membership, and gender and job satisfaction were not predictors of union members. This study had managerial implications, in the sense that when hiring employees on a part-time basis, having employees who are committed and offering employees QWL (i.e. excellent fringe benefits) will impact negatively on union membership. In terms of policymakers, the study revealed that developing remuneration policies that are pro-employee (i.e. offering excellent working conditions and fringe benefits) would make them satisfied, possibly be productive, and they would engage less in counterproductive industrial actions like strikes, which in South Africa are the amongst highest in the world.
\end{abstract}

Keywords: Biographical, human resource management, low and middle-income workers, South Africa, union membership

\section{Introduction}

Union membership means employees who are registered with a union and enjoy benefits like being represented in grievances (Bendix, 2015), disciplinary hearings (Venter \& Levy, 2015), and earn a living wage that will enable them to live a good quality of life (Anker, 2011). Conversely, employees who are not unionized are hired on a part-time basis, do not have specialized skills demanded by employers (Slabbert, Parker \&Farrel, 2015) and earn lower wages (Maleka, 2012). In South Africa, unions operate under a collective agreement and negotiate for better working conditions and wages of employees irrespective of whether they are unionized or not (Bendix, 2015). Non-union employees who benefit from the collective agreements negotiated are known as free riders and in terms of the Labor Relations Act (LRA), No. 66 of 1995, such employees must pay an agency fee (Finnemore, 2013). Literature from the United States of America (USA), and Europe suggests that union membership is decreasing (Fitzenberger, Kohn \&Lembck, 2008; Western \& Rosenfeld, 2011; Markey \& Townsend, 2013) and management control is on the rise (Maiorescu, 2016). Management approaches to union membership differ from country to country. For example, in Germany, through the policy of co-determination, managers have to include union leadership in strategic planning as members of the top management (Gumbrell-MacCormick \& Hyman, 2010). The results have been positive because Germany is known for precision and producing high-quality products. A South African study where employees were engaged also yielded positive outcomes -involving and getting buy-in from union members helped the organization to increase profit (Nienaber \& Martins, 2016). On the contrary, other organizations in South Africa have seen a spike in labor unrest, which has impacted negatively on productivity (Nel, Kirsten, Swanepoel, Erasmus \& Jordaan, 2016). In the 1980s, in the United Kingdom (UK), productivity increased after unions were weakened by passing labor legislation that discouraged union membership (Mason \& Bain, 1993). Trends show that South African productivity has been adversely affected by strikes (Nel et al., 2016); hence some employers have a negative attitude towards a high number of union members and prefer temporary workers (Coetzee \&Schreuder, 2016).

There are interesting trends on how biographical factors and HRM outcomes predict union membership (see Turner, Cross \& O'Sullivan, 2014). An Australian study, showed that women who were unionized were more satisfied because they received training opportunities, as compared to women who were not unionized 
(Oliver, 2010; Waddoups, 2014). Another study showed that the mean scores of job satisfaction were higher for employees who were unionized than the employees who were not part of trade unions (Garcia-Serrano, 2009). Berglun (2014) argued that in Nordic countries, union membership is sustained because workers are satisfied with the benefits and working conditions (i.e. QWL). A review of labor relations literature revealed that there is little research on the biographical and HRM predictors of union membership of low- and middleincome workers in the South African context. Instead, the focus has been on wage inequality (Ntuli \& Kwenda, 2014), wages (Godfrey, Maree, Du Toit \& Theron, 2014), job security (Finnemore, 2009), andrepresentation during grievance and disciplinary hearings (Bendix, 2015; Venter \& Levy, 2015). Low-income workers are employees who are paid low salaries and in most cases they are women, black, and most of them do not have a National Senior Certificate. In South Africa, they earn between R570 to R2 300 per month (Statistics South Africa [Stats SA], 2014). Using price capita per month in 2014 to determine poverty trends, economics determined the lower poverty line as R712 and upper poverty line as R1 312 (Morh, Yu \&Mollentze, 2016). Research revealed that employees earning less than R10 000 are low-income workers and those who earn more than R10 000 are middle-income workers (Carr, Maleka, Meyer, Barry, Parker \& Haar, 2017). Employees earn low wages because they are not unionized and part of the collective agreement (Stats SA, 2014).

This study is important because it addresses the gap in the South African literatureasit covers HRM variables (i.e. employee engagement, job satisfaction, quality of work-life [QWL], and organizational commitment) that are usually neglected as predictors of union membership in South African labor relations literature. In South Africa, predictors of union membership are based on decent wages (Mmolaeng\&Bussin, 2012), job security, political affiliation, race, and representation during grievances and disciplinary hearings (Nel et al., 2016). The researcher conducted a study on low- and middle-income workers in Tshwane, one of the metropolitan cities in South Africa. According to the Tshwane Research Unit (2013), the population in Tshwane in 2013 was 2.4 million, of which almost $40 \%$ were low-income workers. Discussed in the next section is the literature on predictors or determinants of union membership, the methodology followed to address the research problem, and the study results. The paper concludes with the discussion of the results and prior research, managerialimplications, and recommendations.

\section{Literature Review}

Biographical predictors of union membership: There is evidence that gender plays a role in union membership (Bean \&Holde, 1994; Blanchflower, 2007; Maiorescu, 2016). Women are less likely to be unionized (Western \& Rosenfeld, 2011) because they perceive shop stewards to be ineffective in communicating information about workplace decisions (Nthani, 2017) and negotiating for equal wages (Casale \& Posel, 2009). Employees who are not permanently employed are less likely to be unionized due to the type of employment contract they have signed (Bendix, 2015). The following hypotheses are therefore put forward:

H1A: Males who are committed are more likely to be unionized than females.

H1B: Permanent employees are more likely to be unionized than part-time employees.

Human resource management (HRM) predictors of union membership: Meyer and Allen (1997) developed an organizational commitment model. Meyer and Allen's model measured three dimensions, which are affective, normative, and continuance commitment, and it has been validated in different organizations globally (Stephens, Dawley \& Stephens, 2004; Seibert, Wang \&Courtright, 2011; Brunetto, Teo, Shacklock \& Farr-Wharton, 2012; Coetzee, Mitonga-Monga \& Swarts, 2014). The other model of commitment, which is not organization based but is used to measure union members, was developed by Newton and Shore (1992). In this study, Meyer and Allen's model was deemed appropriate because the researcher was interested in measuring whether affective, continuance, and normative items predict union membership. The review of the literature showed that employees who worked under managers who were not democratic would not be committed to the organization and would be unionized (Sarkar, 2012). The following hypothesis is therefore put forward:

H2: Employees who are less committed are more likely to be unionized. 
Collectively, employees who are unionized are engaged through workplace and bargaining forums in South Africa (Godfrey et al., 2014). Engaging union members collectively is not peculiar to South Africa, but is a global phenomenon (Chan \& Hui, 2010; Compte \& Jehiel, 2010; Muneer et al., 2014). Despite volumes of literature on collective engagement and union membership, there is little research on how individual engagement dimensions like absorption, vigor, and dedication, developed by Schaufeli, Salanova, GonzálezRomá, and Bakker (2002), predict union membership. According to Nienaber and Martins (2016), employees who are engaged are more likely to be unionized. At an individual level, employees who are members of unions thatengage employees through online media (Maiorescu, 2016) are more likely to be engaged than non-unionized employees (Maleka, Schultz, Van Hoek, Dachapalli \& Ragadu, 2017). The following hypothesis is therefore put forward:

H3: Employees who have a high individual level of engagement are more likely to be unionized thannonunionized members.

QWL is viewed as an effort of a union to involve its leadership in working together with management (Lawler III \& Drexler Jr., 1977) and to enhance customer satisfaction and/or implement new technology in the workplace (Fields \& Thacker, 1987). For the purpose of this study, QWL is when an employee is satisfied with the working conditions and fringe benefits (Maleka et al., 2017) negotiated by trade unions (Fields \& Thacker, 1987). It was found that research on QWL tends to focus on union leadership, at the expense of focusing on how employees perceived union membership (Holley, Field \& Crowley, 1981). A study conducted in the USA revealed that QWL was a predictor of union membership (Flavin \& Shufeldt, 2016). Flavin and Shufeldt (2016, p.171) found that "union members are more satisfied with their lives than those who are not members and that substantive effect on union membership on life satisfaction rivals other predictors of QWL". The following hypothesis is therefore put forward:

H4: Employees who have good QWL are more likely to be unionized as opposed to non-unionized members.

Job satisfaction as an HRM variable plays a significant role in determining whether employees are unionized or not (Gordon \& Denisi, 1995; Bluem \& Van Zwam, 1997; Hammer \& Avgar, 2005; Hipp \& Givan, 2015; Laroche, 2016; Colley, 2017). Smith, De Beer and Pienaar (2016) found that there was an association between job satisfaction and union membership. An international study revealed that unionized employees in low economic countries are satisfied, it negotiated for good working conditions (Charman \& Owen, 2014). Union members are more likely to be satisfied than non-unionized members because they receive company benefits, for example training opportunities (Waddoups, 2014), fair and equitable policy, and negotiating a living wage (Mmolaeng \& Bussin, 2012; Tufail et al., 2016). Conversely, studies conducted in the late 1970s showed that employees who were unionized were more dissatisfied compared to non-unionized employees (Borjas, 1979; Freeman, 1979). The commonality of the studies is that they used econometrics techniques to predict job satisfaction. Also, in the literature, it was evident that thereis a lack of research measuring job satisfaction as a predictor of union membership using statistical techniques like logistic regression. The following hypothesis is therefore put forward:

H5: Employees who are satisfied are more likely to be unionized than non-unionized members.

\section{Methodology}

Discussed in this section are research approach, design and paradigm, sampling, research instrument, reliability and validity, and data analysis.

Research approach, design, and paradigm: The research approach that assisted the researcher to address the research hypotheses was quantitative, because the researchers wanted to quantify the effects and differences of HRM outcomes on union membership. The research design was cross-sectional and descriptive. The research paradigm that influenced the study was positivism, and the researchers created new knowledge by testing hypotheses (i.e. epistemological stance) and were objective when they analyzed the data (ontological stance) (Du Plooy-Cilliers, Davis \& Bezuidenhout, 2014).

Sampling: Purposive sampling was used at Marabastad Mall because the researcher knew that it was a place where unionized and non-unionized employees could be found. One thousand $(\mathrm{N}=1000)$ questionnaires were printed, and 874 were completed. The sample size was sufficient to conduct logistic regression, because it 
was above 400 sample size threshold recommended by Hair, Black, Babin and Anderson (2014). The response rate was $87.40 \%$. The response rate is above the $10 \%$ threshold suggested by Bless, Higson-Smith and Sithole (2013).

Research instrument, reliability, and validity: The research instrument used for data collectionwas a validated questionnaire. The questionnaire did not take respondents a long time to complete (Maree, 2007; Neuman, 2014). The researcher hired research assistants who spoke the language understood by the respondents who visited the research site. In some instances, the research assistants translated the questionnaire items for respondents who did not understand English. Section A of the questionnaire comprised biographical information. Table 1 shows that the majority (67.10\%) of the respondents were not unionized. In terms of gender, $51.70 \%$ of the respondents were males. The majority $(88.80 \%)$ of the respondents' ages ranged from 25 to 54 .

Table 1: Biographical information

\begin{tabular}{lll}
\hline Variable & Frequency & Percentage \\
\hline Trade union membership & Yes (589) & $67.10 \%$ \\
& No (280) & $31.90 \%$ \\
Gender & Male (454) & $51.70 \%$ \\
& Female (421) & $47.90 \%$ \\
\hline
\end{tabular}

Section B had three scales. Nine items of job satisfaction were taken from a scale developed by Spector (1985) and after deleting the following items, the Cronbach's alpha was 0.86: There are few rewards for those who work here; I don't like the people I work with; I find I have to work harder than I should because of the incompetence of the people I work with. Nine items were taken from the quality of work-life scale developed by Timossi, Pedroso, De Fransicoand Pilatti (2008) and after deleting the following variables, the Cronbach's alpha increased to 0.72: I am under pressure to meet deadlines; I often find myself thinking about work instead of focusing on home/leisure activities; I find it hard to take time off during work to take care of personal and family matters; andIt is difficult to concentrate on because of home matters. Nine items of organizational commitment were taken from a scale developed by Meyer and Allen (1997) and after deleting the following items, the Cronbach's alpha was 0.71: It should be very hard for me to leave my organization right now, even when I wanted to; Right now, staying with my organization is a matter of necessity as much as a desire; One of the major reasons I continue to work for this organization is that I believe that loyalty is important and I therefore feel a sense of moral obligation to remain; and I think that people these days move from company to company too often. Items in Section B were measured on a five-point Likert scale where 1 is strongly disagree and 5 is strongly agree.

Section C had nine employee engagement items, taken from Schaufeli et al. (2002). None of the items were deleted and the Cronbach's alpha was 0.89. A sample of the questions is as follows: At my work, I feel bursting with energy; My job inspires me; and I am happy when I work intensely. The items had a seven-point Likert scale, and the alpha coefficient in this study was 0.91 . Since the factor loadings of all the items retained were above 0.70, it can be argued that construct validity was achieved (Field, 2013; Struwig \& Stead, 2013). Prior to data collection, the researcher was given ethical clearance by the university to conduct the study and the questionnaire was pretested on 20 respondents.

Data analysis: Data were coded in Microsoft Excel and exported into the Statistical Package for the Social Sciences (SPSS) version 24 for analysis. The univariate analysis comprised frequencies and logistic regression and was used to address the study's hypotheses. The latter was used because the dependent variable was binary, where "Yes" was coded as 1 and "No "wascoded as 0 (Kleinbaum\& Klein, 2010). As suggested by Pallant (2016), model fit was conducted by means of a chi-square $\left(\chi^{2}\right)$ and variancewas measured by means of the Cox and Snell R-square and Nagelkerke R-square.

\section{Results}

This section comprises testing for model fit and hypotheses testing. 
Testing for model fit: Binarylogistic regression was performed to assess the impact of a number of factors on the likelihood that respondents would report union membership. The model contained four predictor variables (employee engagement, QWL, job satisfaction, and organizational commitment). Table2 displays that the model containing predictor variables was statistically significant (Pearson chi-squared $\left(\chi^{2}\right)$ at $(4$, $\mathrm{N}=857)=248.541, \mathrm{p}<0.05)$, indicating that it distinguished between those who were unionized and not unionized.

Table: 2: Omnibus tests of model coefficients

\begin{tabular}{lrccl}
\hline & Chi-square & Df & Sig. \\
\hline Step 1 & Step & 248.541 & 10 & .000 \\
& Block & 248.541 & 10 & .000 \\
& Model & 248.541 & 10 & .000 \\
\hline
\end{tabular}

As can be observed from Table 3, the model can potentially explain between $27.20 \%$ (Cox \& Snell R-square) and $37.90 \%$ (Nagelkerke R-square) of the variance in union membership.

Table 3: Model summary

\begin{tabular}{llll}
\hline Step & -2 Log likelihood & Cox \& Snell R-square & Nagelkerke R-square \\
\hline 1 & $741.956 a$ & .272 & .379 \\
\hline
\end{tabular}

a. Estimation terminated at iteration number 4 because parameter estimates changed by less than .001 .

The data not displayed in the paper correctly classified $76.40 \%$ of cases. The Hosmer-Lemeshowgoodness-offit test (see Table 4) indicated a non-significant value (.510), meaning that our model fit the data satisfactorily (Kleinbaum\& Klein, 2010; Hosmer, Lemeshow\& Sturdivant, 2013; Pallant, 2016).

Table 4: Hosmer-Lemenshowtest

\begin{tabular}{cccc}
\hline Step & Chi-square & df & Sig. \\
\hline 1 & 15.478 & 8 & .510 \\
\hline
\end{tabular}

Hypotheses testing: As discussed in the methodology section, logistic regression (refer to the SPSS output in Table 5) was used to test the hypotheses.

Table 5: Predictors of union membership

\begin{tabular}{llllllll}
\hline & & B & S.E. & Wald & df & Sig. & Exp(B) \\
\hline Step 1a & Gender & .181 & .186 & .944 & 1 & .331 & 1.198 \\
& Employment status & -1.782 & .279 & 40.936 & 1 & .000 & .168 \\
& Organizational commitment & -.802 & .101 & 62.860 & 1 & .000 & .448 \\
& Employee engagement & .222 & .095 & 5.512 & 1 & .019 & 1.249 \\
& QWL & -.380 & .119 & 10.249 & 1 & .001 & .684 \\
& Job satisfaction & .128 & .099 & 1.681 & 1 & .195 & 1.137 \\
& Constant & 5.386 & .739 & 53.152 & 1 & .000 & 218.248 \\
\hline
\end{tabular}

The data in Table 5 show that gender was not a predictor of union membership $(\beta=.181 p>0.05)$. Based on the study results, $\mathrm{H} 1 \mathrm{a}$ is not supported. The data also revealed that employment status is a predictor of union membership $(\beta=-1.782, p<0.05)$. This indicates that permanent employees are .168 less likely to be unionized compared to part-time employees. Therefore, H1b cannot be supported. The data also revealed that organizational commitment was a predictor of union membership $(\beta=.222, \mathrm{p}<0.05)$. This indicates that employees who are committed, are0.448 less likely to be unionized. Based on the study results, $\mathrm{H} 2$ is not supported. It can also be observed from Table 5 that employee engagement was a predictor of union membership $(\beta=.222, \mathrm{p}<0.05)$. This means that employees who are engaged, are 1.249 more likely to be unionized. Hypotheses H3 is therefore supported. It was also found in this study that QWL was a predictor of union membership $(\beta=-.380, p<0.05)$. This indicates that employees with high QWL are 0.684 times less likely to be unionized. $\mathrm{H} 4$ is thus not supported. Lastly, the data revealed that job satisfaction was not a 
predictor of union membership $(\beta=.128, \mathrm{p}>0.05)$. This indicates that employees who are satisfied are 0.195 more likely to be unionized than non-unionized members. H5 is therefore not supported.

\section{Discussion}

The purpose of the study was to identify biographical (i.e. gender and employment status) and HRM outcomes (i.e. employee engagement, QWL, job satisfaction and organizational commitment) as predictors of union membership. The data revealed that gender was not a predictor of union membership. This finding contradicts previous research that showed that gender was a predictor of union membership (Bean \&Holde, 1994; Blanchflower, 2007; Maiorescu, 2016) and that females were less likely to be unionized than males (Western \& Rosenfeld, 2011). Interestingly, the data showed that employees who were working on a full-time based were less likely to be unionized, as compared to employees who were employed on a part-time basis. This finding is in contrast with the literature (Bendix, 2015). This implies that employees employed permanently did not see the benefits or the importanceof the roles that unions play, like negotiating for decent wages (Mmolaeng \& Bussin, 2012) and job security and representation during grievances and disciplinary hearings ( $\mathrm{Nel}$ et al., 2016).Earlier it was argued that this study is salient or important because it covered HRM outcomes (i.e. employee engagement, job satisfaction, QWL, and organizational commitment), which are neglected in South African literature as predictors of union membership. It was found that organizational commitment was a predictor of union membership. Similarly, Sarkar (2012) found that employees who are less committed are more likely to be unionized. The implication of having employees who are less committed is that the unions will have to represent them more often at disciplinary hearings because their lack of commitment can lead them to not coming to work and being charged for poor performance.Unfortunately, the literature showed that South Africa workplaces are less productive due to high labor unrest and employees who are not committed (Nel et al., 2016) and indicated less harmonious employment relations like in Germany, for example(Gumbrell-MacCormick \& Hyman, 2010). It can be argued that employees who are not committed and are protected by the unions can also adversely affect the morale of committed employees.

Consistent with the literature (see Maleka et al., 2017), it was found that employees who are engaged are more like to be unionized. At an organizational level, Nienaber and Martins (2016) discovered that South African management who were engaged or worked collaboratively with unions increased the profit margins of the organizations. Contrary to Flavin andShufeldt's (2016) findings, the data in this study showed that employees with a high QWL were less likely to be unionized. This implies that employees with high QWL valued their skills as proxy to better wages, and did not perceive being unionized as an enabler of decent wages and working conditions (Fields \& Thacker, 1987). The data showed that employees who are satisfied were more likely to be unionized than those who are unionized. This seems to suggest that unionized employees were satisfied because unions negotiated for better training opportunities (Waddoups, 2014), fair and equitable policy, and a living or decent wage (Mmolaeng \& Bussin, 2012).

This study has managerial implications, in the sense that when hiring employees on a part-time basis, having employees who are committed, and offering employees QWL (i.e. excellent fringe benefits) will impact negatively on union membership. Hiring employees earning less than R203 000 on a part-time basis without proper reasons might lead to labor disputes because it is against section 198(c) of the LRA of 1995, which states that if employees are hired for more than three months, their contract must be converted to a permanent basis (Casual Workers Advice Office, 2015). In terms of policymakers, the study revealed that developing remuneration policies that are pro-employee (i.e. offering excellent working conditions and fringe benefits) would make them satisfied, possibly productive, and they would be less engaged in counterproductive industrial actions like strikes. In South Africa, a minimum wage of R3 500, which is above the lower- and upper-poverty lines determined by economics (see Morh et al., 2016), will be implemented in May 2018.It is recommended that organizations should:

- hire employees on a part-time basis in accordance with section 198(c) of the LRA and train them to be productive;

- encourage employees to be unionized, offer them decent wages, and treat them fairly and equally to keep them satisfied;

- offer employees fringe benefits that will enhance their QWL; and 
- work collaboratively with unions to gain buy-in to implement organization strategy and increase profit margins.

In terms of the unions, it is recommended that they work together with management as in Germany, so that they can increase their membership and be involved in the strategic decision-making in organizations (Gumbrell-MacCormick \& Hyman, 2010). In South Africa, it was found that when there is a co-determination between unions and managers; the latter had a high membership and assisted organizations in reaching business objectives (Nienaber \& Martins, 2016). This study brought new insight on how to predict union membership, and since it was based on a cross-sectional research design, it is recommended that it is conducted over a longer period to determine if the same trends will emerge. In future, researchers can use a mixed-methods design, so that they can also solicit qualitative data that will shed more light on the quantitative predictors of union membership.

Acknowledgement: I am grateful to Professor Carr who guided me in 2015 on how to conduct multiple living wage projects in South Africa. I am also grateful to Mr Lanre Adediran who assisted me to conceptualize the study. Emile Saker from Ozmos Consulting, thank you for the statistical coaching. The data used in this study were collected with esteemed colleagues, Drs. Dachapalli and Van Hoek, and Professor Schultz and Mrs. Ragadu from People Management and Development. I am grateful to the Department of Higher Education and Training, through the Research and Innovation Directorate at Tshwane University of Technology for awarding me a grant in 2016 to visit Massey University in New Zealand.

\section{References}

Anker, R. (2011). Estimating a Living Wage: A Methodological Review. International Labor Organization, 29, 1-126.

Bean, R. \& Holde, K. (1994). Determinants of Trade Union Membership in OECD Countries: A Survey. International Journal of Manpower, 15(6), 4-35.

Bendix, S. (2015). LabourRelations: A Southern African Perspective (6th ed), Cape Town: Juta.

Berglun, T. (2014). Crisis and Quality of Work Life in the Nordic Employment Regime. International Review of Sociology, 24(2), 259-269.

Blanchflower, D. G. (2007). International Patterns of Union Membership. British Journal of Industrial Relations, 45(1), 1-28.

Bless, C., Higson-Smith, C. \& Sithole, S. L. (2013). Fundamentals of Social Research Methods. An African Perspective ( $5^{\text {th }}$ ed), Cape Town: Juta and Company, Ltd.

Bluem, S. D. \& Van Zwam, C. (1997). Trade Union and Job Satisfaction. South African Journal of Psychology, $17(4), 160-164$.

Borjas, G. J. (1979). Job Satisfaction, Wages and Unions. Journal of Human Resources, 14(1), 21-40.

Brunetto, Y., Teo, S. T. T., Shacklock, K. \& Farr-Wharton, R. (2012). Emotional Intelligence, Job Satisfaction, Well-being and Engagement: Explaining Organisational Commitment and Turnover Intentions in Policing. Human Resource Management Journal,22(4), 428-441.

Carr, S. C., Maleka, M. J., Meyer, I., Barry, M. L., Parker, J. \& Haar, J. (2017). Sustainable Livelihood in Two Diverse Economies: From Working Poverty to Living Wages. (In press.)

Casale, D. \& Posel, D. (2009). Unions and the Gender Wage Gap in South Africa. Journal of African Economies, 20(1), 27-59.

Casual Workers Advice Office. (2015). Summary Labour Relations Act 2014 Section 198. New Rights for Labour Broker Workers, Contract Workers and Part-time Workers. Available at: http://www.cwao.org.za/downloads/BIG\%20NEW\%20RIGHTS\%20Feb\%202015-summary.pdf.

Chan, C. K. \& Hui, E. S. (2010). The Development of Collective Bargaining in China: From Collective Bargaining by Riot to Party-led Wage Bargaining.The China Quarterly, 217, 221-242.

Charman, C. \& Owen, A. L. (2014). Collective Happiness: Labour Union Membership and Life Satisfaction. Applied Economics Letters, 21(13), 924-927.

Coetzee, M., Mitonga-Monga, J. \& Swarts, B. (2014). Human Resource Practices as Predictors of EngineeringStaff'sOrganisational Commitment. South African Journal of Human Resource Management, 12(1), 1-9.

Coetzee, M. \& Schreuder, D. (2016). Personnel Psychology: An Applied Perspective. Cape Town: Oxford University Press. 
Colley, L. (2017). Union Recognition and Union Security: Steps to the Left and Jumps to the Right in an Australian State. Journal of Management History, 23(1), 95-110.

Compte, O. \& Jehiel, P. (2010). Bargaining and Majority Rules. Journal of Political Economy, 118(2), 189-221.

Drexler Jr., J. A. \& Lawler III, E. D. (1977). A Union-management Cooperative Project to Improve Quality of Work-life. The Journal of Applied Behavioral Science,13(3), 373.

Du Plooy-Cilliers, F., Davis, C. \& Bezuidenhout, R. (2014). (Eds.). Research Matters. Claremont: Juta.

Field, A. (2013). Discovering Statistics using IBM SPSS Statistics (4th ed), London: Sage Publications.

Fields, M. W. \& Thacker, J. W. (1987). Union Involvement in Quality of Work-Life Efforts: A Longitudinal Investigation. Personnel Psychology, 40,99-111.

Finnemore, M. (2009). Introduction to Labour Relations in South Africa (10th ed), Durban: LexisNexis.

Finnemore, M. (2013). Introduction to Labour Relations in South Africa (11th ed), Durban: LexisNexis.

Fitzenberger, B., Kohn, K. \& Lembck, A. C. (2008). Union Density and Varieties of Coverage: The Anatomy of Union Wage Effects in Germany. London, United Kingdom: Centre for Economic Performance, London School of Economics and Political Science.

Flavin, P. \& Shufeldt, G. (2016). Labor Union Membership and Life Satisfaction in the United States. Labor Studies Journal,41(2), 171-184.

Freeman, R. B. (1978). Job Satisfaction as an Economic Variable. American Economic Review,62(8), 135-141.

Garcia-Serrano, C. (2009). Job Satisfaction, Union Membership and Collective Bargaining. Journal of Industrial Relations, 29(1), 49-65.

Godfrey, S., Maree, J., Du Toit, D. \& Theron, J. (2014). Collective Bargaining in South Africa: Past, Present and Future. Claremont: Juta.

Gollbach, J. \& Schulten, T. (2000). Cross-border Collective Bargaining Networks in Europe. European Journal of Industrial Relations, 6(2), 161-179.

Gordon, M. E. \& Denisi, A. (1995). A Re-examination of the Relationship between Union Membership and Job Satisfaction. Industrial and Labor Relations Review, 48(2), 222-236.

Gumbrell-MacCormick, J. \& Hyman, R. H. (2010). Managing Employee Relations (5th ed), London: Chartered Institution of Personnel and Development.

Hair, J. F., Black, W. C., Babin, B. J. \& Anderson, R. E. (2014). Multivariate Data Analysis. Harlow: Pearson.

Hammer, T. H. \& Avgar, A. (2005). The Impact of Unions on Job Satisfaction, Organizational Commitment, and Turnover. Journal of Labour Relations, 26(2), 241-266.

Hipp, R. K. \& Givan, R. K. (2015). What do Unions do? A Cross National Re-examination of the Relationship between Unionization and Job Satisfaction. Social Forces, 94(1), 349-377.

Holley, W. H., Field, H. S. \& Crowley, J. C. (1981). Negotiating Quality of Work-life, Productivity and Traditional Issues: Union Members' Preferred Roles of their Members. Personnel Psychology,34, 309-328.

Hosmer, D. V., Lemeshow, S. \& Sturdivant, R. X. (2013). Applied Logistic Regression (3rded), New Jersey: John Wiley \& Sons.

Khan, L. M. (2000). Inequality, Collective Bargaining, and Relative Employment from 1985 to 1994: Evidence from Fifteen OECD Countries. The Review of Economics and Statistics, 82(4), 564-579.

Kim, C. (2014). Employee Determinants of Employee State Union of Union Density in the United States. International Journal of Public Sector Management,27(1), 53-65.

Kleinbaum, D. G. \& Klein, M. (2010). Logistic Regression: A Self-Learning Text. New York: Springer.

Laroche, P. (2016). A Meta-analysis of the Union-job Satisfaction Relationship. British Journal of Labor Relations, 54(4), 709-741.

Maiorescu, R. D. (2016). Using Online Platform to Engage Employees' Unionism: The Case of IBM.Public Relations Review, 1-6.

Maleka, M. J. (2012). An In-depth Investigation of the Factors Contributing to Employee Dissatisfaction at the Business Application Solution Centre (BASC), Eskom. (Doctorate thesis.) Pretoria: University of South Africa (UNISA).

Maleka, M. J., Schultz, C., Van Hoek, L., Dachapalli, L. \& Ragadu, S. (2017). Measuring Employee Engagement of Low-income Workers either Working or Visiting Marabastad Mall in the Tshwane Metropolitan Municipality. Journal of Economics and Behavioral Studies, 9(6),74-82.

Markey, R. \& Townsend, K. (2013). Contemporary Trends in Employee Involvement and Participation. Journal of Industrial Relations, 55(4), 475-487.

Mason, B. \& Bain, P. (1993). The Determinants of Trade Union Membership: A Survey of the Literature. Industrial and Labor Relations Review, 42(2), 332-351. 
Maree, K. (2007). First Steps in Research. Pretoria: Van Schaik.

Meyer, J. P. \& Allen, N. J. (1997). Commitment in the Workplace. Thousand Oaks, CA: Sage Publications.

Mmolaeng, M. \& Bussin, M. (2012). Drivers of Public Wage Demandsand Union Demands in a Lowrecessionary Environment in South Africa. South African Labour Relations Journal, 36(1), 69-85.

Morh, P., Yu, D. \& Mollentze, S. (2016). Economic Indicators (5th ed), Hatfield: Van Schaik Publishers.

Muneer, S., Iqbal, S. M. J., Khan, S. U. \& Long, C. S. (2014). An Incorporated Structure of Perceived Organizational Support, Knowledge-Sharing Behavior, Organizational Trust and Organizational Commitment: A Strategic Knowledge Management Approach. Pakistan Journal of Commerce and Social Sciences, 8(1), 42- 57

Nel, P. S., Kirsten, M., Swanepoel, B. J., Erasmus, B. J. \& Jordaan, B. (2016). South African Employment Relations: Theory and Practice (16th ed), Pretoria: Van Schaik Publishers.

Nienaber, H. \& Martins, N. (2016). (Eds.).Employee Engagement in a South AfricanContext. Randburg: K.R. Publishing.

Neuman, W. L. (2014). Basics of Social Research: Qualitative and Quantitative Approaches (3rd ed.), Harlow: Pearson.

Newton, L. A. \& Shore, L.M. (1992). A Model for Union Membership: Instrumentality, Commitment and Opposition. Academy of Management Review, 17(2), 275-298.

Nthani, G. (2017). Daybreak Farms Employee Perceptions of the Benefits of Trade Union Membership. (Master's thesis.) Pretoria: Tshwane University of Technology.

Ntuli, M. \& Kwenda, P. (2014). LabourUnions and Wage Inequality among African Men in South Africa. Development Southern Africa, 31(2),322-346.

Oliver, D. (2010). Union Membership among Young Graduate Workers in Australia: Using the Experience Good Model to Explain the Role of Student Employment. Industrial Relations Journal, 41(5), 505-519.

Pallant, J. (2016). SPSS Survival Manual: A Step-by-step Guide to Data Analysis using IBM SPSS (6th ed), Crows Nest: Allen \& Unwin.

Sarkar, S. (2012). Determinants of Employees' Attitude toward Union Membership. Journal of World Business, $47,240-250$.

Schaufeli, W. B., Salanova, M., González-Romá, V.\& Bakker, A. B. (2002). The Measurement of Engagement and Burnout: A Two-sample Confirmatory Factor Analytic Approach. Journal of Happiness Studies, 3, 7192.

Seibert, S. E., Wang, G. \& Courtright, S. H. (2011). Antecedents and Consequences of Psychological and Team Empowerment in Organizations: A Meta-Analytic Review. Journal of Applied Psychology, 96(5), 9811003.

Slabbert, J. A., Parker, A. J. \& Farrel, D. V. (2015). Employment Relations Management. Back to Basics: A South African Perspective. Durban: LexisNexis.

Smith, N. W. H., De Beer, L. T. \& Pienaar, J. (2016). Work Stressors, Job Insecurity, Union Support, Job Satisfaction andSafety Outcomes within the Iron Ore Mining Environment: Original Research. South African Journal of Human Resource Management, 14(1), 1-13.

Spector, P. (1985). Measurement of Human Service Staff Satisfaction: Development of Job Satisfaction Survey. American Journal of Community Psychology,13, 693-713.

Statistics South Africa (Stats SA). (2014). Quarterly Labour Force Survey. Available at: http://beta2.statssa.gov.za/publications/P0211/P02111stQuarter2014.pdf.

Stephens, R. D., Dawley, D. D. \& Stephens, D. B. (2004). Commitment on the Board: A Model of Volunteer Directors' Levels of Organization. Journal of Managerial Issues, 16(4), 483-504.

Struwig, F. W. \& Stead, G. B. (2013). Research: Planning, Designing and Reporting (2nd ed), Cape Town: Pearson.

Sullivan, R. (2010). Labor Market and Labor Movement? The Union Density Bias as a Barrier to LabourRenewal. Work, Employment and Society, 24(1), 145-156.

Timossi, L. D., Pedroso, B., De Fransico, A. C. \& Pilatti, L. A. (2008). Evaluation of Quality of Work Life: An Adaptation from the Walton's QWL Model. Paper presented at the XIV International Conference on Industrial Engineering and Operations Management (ICIEOM). Rio de Janeiro, Brazil, 13-16 October 2008.

Tshwane Research Unit. (2013). City of Tshwane General and Regional Overview. Available at: http://www.parliament.gov.za/content/Tshwane_General_and_Regions_Report_2013.pdf. 
Tufail, M. S., Muneer, S. \& Ishtiaq, M. (2016). Job Characteristics with Task and Contextual Performance: Moderating Role of Procedural Justice for Front Line Managers. Journal of Social Sciences, Special Issue, 299-508

Turner, T., Cross, C. \& O'Sullivan, M. (2014). Does Union Membership Benefit Immigrant Workers in 'HardTimes'? Journal of Industrial Relations,56(5),611-630.

Venter, R. \& Levy, A. (2015). (Eds.). Labor Relations in South Africa (5th ed), Cape Town: Oxford University Press.

Waddoups, C. J. (2014). Union Membership and Job-related Training: Incidence, Transferability, and Efficacy. British Journal of Industrial Relations,52(4), 753-778.

Western, B. \& Rosenfeld, J. (2011). Unions, Norms and the Rise of Union Inequality. American Sociological Review,76(4), 513-517. 